\title{
Relationships in Patagonian species of Berberis (Berberidaceae) based on the characterization of rDNA internal transcribed spacer sequences
}

\author{
M. C. J. BOTTINI ${ }^{1,2,3}$, A. DE BUSTOS ${ }^{4 *}$, A. M. SANSO ${ }^{2,5}$, N. JOUVE ${ }^{4}$ and L. POGGIO ${ }^{2,3}$ \\ ${ }^{1}$ Instituto de Ecología y Evolución, Facultad de Ciencias, Campus Isla Teja, Casilla 567, Universidad \\ Austral de Chile, Valdivia, Chile \\ ${ }^{2}$ Facultad de Ciencias Exactas y Naturales, Universidad de Buenos Aires, Intendente Güiraldes y \\ Costanera Norte (C1428EHA), Buenos Aires, Argentina \\ ${ }^{3}$ CIGen-CONICET (B1836AML) Llavallol, Argentina \\ ${ }^{4}$ Department of Cell Biology and Genetics, University of Alcalá, Campus Universidad de Alcalá, Alcalá \\ de Henares, Madrid, Spain \\ ${ }^{5}$ Facultad de Ciencias Veterinarias, Universidad Nacional del Centro de la Provincia de Buenos Aires, \\ Paraje Arroyo Seco s/n, (B7000) Tandil, Argentina
}

Received January 2005; accepted for publication July 2006

\begin{abstract}
Sequence analysis of the internal transcribed spacer (ITS) of the 18S(ITS1)-5.8S-26S(ITS2) rDNA region was performed in order to analyse the phylogenetic relationships between 13 Patagonian species of the genus Berberis (Berberidaceae). The divergence values between the pairwise sequence in the studied Patagonian species were in the range 2.9-22.9\%. The lengths of the ITS1 and ITS2 sequences were in the range 227-231 bp and 220-224 bp, respectively, and the 5.8S sequence was $159 \mathrm{bp}$ throughout all species. B. microphylla sensu Landrum does not appear to be monophyletic based on current sampling. Indeed, we suggest that B. microphylla should be distinguished from B. buxifolia, B. parodii, and B. heterophylla. ITS sequences, together with data obtained from morphological, biochemical, amplified fragment length polymorphism, and cytological characterizations, support the existence of diploid and polyploid hybrid speciation in the genus. (C) 2007 The Linnean Society of London, Botanical Journal of the Linnean Society, 2007, 153, 321-328.
\end{abstract}

ADDITIONAL KEYWORDS: Argentina - barberry - calafate - diploid and polyploid hybrid speciation michay - molecular markers.

\section{INTRODUCTION}

The Berberidaceae is a family of about 15 genera and more than 650 species spread in the Northern Hemisphere, with a single genus, Berberis L., extending into temperate and Andean South America (Loconte, 1993). They are evergreen and semi-evergreen shrubs or small trees, often spiny, with inflorescences as racemes, umbels, or solitary flowers of yellow, orange to red-orange, that grow under a wide range of ecological conditions (Landrum, 2003).

Ahrend (1961) recognized about 500 species for Berberis s.s. The genus has two important centres of diversity, corresponding to Eurasia with c. 300 species and

*Corresponding author. E-mail: alfredo.bustos@uah.es
South America with $c$. 200 species. However, according to Landrum (1999), this number could be less, as Ahrend cited 60 species for Chile and adjacent southern Argentina, whereas Landrum accepted only 20.

Orsi (1976), in her taxonomic treatment of the Argentinian Berberis species, cited 26 taxa with two disjunct centres of distribution: firstly, the tucumanosalteño forest in the north-west with nine taxa and, secondly, the steppe and the Andean-Patagonian forests in the south. In the latter habitat, the 'calafate' or 'michay', names applied to many of the Patagonian Berberis species, are very common elements of the under-forest, steppe, and forest-steppe ecotone (Bottini, 2000)

Most of the Berberis species have medical uses because of the presence of alkaloids, principally 'ber- 
berina' (Fajardo Morales, 1992). The fruits are dark purple, black, or bluish berries, rich in sugar and vitamins, that are eaten fresh or prepared as jellies, marmalades, and wines (Martínez Crovetto, 1980). Several Patagonian species, such as B.darwinii Hook., B.trigona Kunze ex Poepp. \& Endl. (=B. linearifolia Phil., Landrum 1999), B. buxifolia Lam., and B. empetrifolia Lam., are used in gardens for their ornamental value (Brickell, 1989). In the steppe, B. heterophylla Juss. ex Poir. is a source of forage and protection for sheep, goats, and wild animals (Bottini, Bustos \& Bran, 1993).

The taxonomy of the genus Berberis is still somewhat uncertain, despite the large number of studies performed. Orsi (1984) recognized 17 Patagonian species in Argentina, whereas Landrum (1999) synonymized several of these species and recognized only nine. An example of this is the placing of B. microphylla G. Forst., B. buxifolia Lam., B. heterophylla Juss. ex Poir., and B. parodii Job under B. microphylla.

The occurrence of hybridization and, perhaps, also some degree of introgression in transitional zones has produced intermediate forms that cause difficulties in Berberis taxonomy (Bottini, Premoli \& Poggio, 1999b).

In recent years, numerous techniques have been performed to contribute to a better knowledge of the Patagonian species. Indeed, morphological, ecological, cytogenetic, and biochemical studies have allowed the delimitation of these taxa and the postulation of homoploid and polyploid speciation (Bottini et al., 1998, 1999b, 2000a; Bottini, Greizerstein \& Poggio, 1999a, 2000b; Bottini, 2000). These data suggest that $B$. bidentata, B. trigona, and B. darwinii form a homogamic hybrid complex, in which B. bidentata has originated from hybridization and is diploid and homoploid with respect to the parental species B. darwinii and B. trigona (Bottini et al., 2002).

Amplified fragment length polymorphism (AFLP) techniques have also been used to analyse the intraand interspecific relationships between the Patagonian species. Correspondence between the AFLP data, morphological traits and seed protein bands has also been demonstrated (Bottini et al., 2002). By contrast, B. buxifolia (4x), B. heterophylla (4x), and B. parodii (2x) appear to form a polyploid complex (Bottini, 2000).

Noncoding sequences, such as internal transcribed spacer (ITS) regions of nuclear genes, have been used to investigate phylogenetic relationships in plants (Hsiao et al., 1994, 1995; Smith \& Klein, 1994; Sun et al., 1994; Lashermes et al., 1997; Dubouzet \& Shinoda, 1999; De Bustos \& Jouve, 2002; De Bustos, Loarce \& Jouve, 2002; Zomlefer et al., 2003). However, there has only been one phylogenetic study based on a comparison of the sequences in the genus Berberis. Recently, whilst our manuscript was being evaluated, Kim, Kim \& Landrum (2004) used ITS sequences to test previous taxonomic hypotheses regarding the classification of Berberis s.l. The present work was designed to review the phylogenetic relationships of the 13 taxa of the genus Berberis by comparing the sequences of the ITS regions. Moreover, these results were compared with those obtained using other sources of data, such as AFLP, isozymes, cytogenetics, seed proteins, and morphology.

\section{MATERIAL AND METHODS}

Thirteen of the 17 Patagonian Berberis species described by Orsi (1984) in Flora Patagonica, representing both trans-Andean and endemic taxa, were sampled for this study. Moreover, B. trifoliolata Moric., a species growing in southern and central Texas, USA (Laferrière, 1991), was chosen as the outgroup. Material was collected from wild populations from Argentina, except for B. trifoliolata, whose sequence was obtained from GenBank (accession number AF174616). Vouchers are deposited at the Instituto de Botánica Darwinion (SI). In order to assess the levels of intraspecific variation in ITS, an additional population was sampled for each species of hybrid origin (B. bidentata) and the polyploid species (B. buxifolia and B. heterophylla).

The species of Berberis included in this analysis, except the outgroup species, have been the subject of chromosome studies (Bottini et al., 1999a, 2000a), and these data are included in Table 1.

Total genomic DNA was extracted from a pool of six to seven seeds per population because of the small size of the seeds. The seeds were crushed and the powder was transferred to Eppendorf tubes. DNA was extracted using the DNeasy Plant Minikit (Qiagen), according to the manufacturer's instructions. The ITS region of nuclear ribosomal DNA of all samples was amplified by polymerase chain reaction (PCR) as a single fragment (ITS1, 5.8S, ITS2) using the primers 'ITS4' (5'-TCCTCCGCTTATTGATATGC-3'; White et al., 1990) and a modified 'ITS5' (White et al., 1990), according to the sequence reported for Glycine Willd. (Eckenrode, Arnold \& Meagher, 1984). The change comprised modifications in three base pairs: $5^{\prime}$ GGAAGGAGAAGTCGTAACAAGG-3'. Jackson et al. (1999) used the same modified sequence for the amplification of the ITS region from $B$. trifoliolata.

The total reaction volume of $50 \mu \mathrm{L}$ contained $200 \mathrm{ng}$ of DNA template, $100 \mathrm{ng}$ of each primer, ITS4 and ITS5, $2.5 \mathrm{mM}$ of deoxynucleoside triphosphates (dNTPs), and $2 \mathrm{U}$ of Taq DNA polymerase (Sigma) in $10 \times$ PCR buffer (Sigma). The PCR profiles were as follows: 30 reaction cycles of $30 \mathrm{~s}$ at $94^{\circ} \mathrm{C}$ (denaturation), $1 \mathrm{~min}$ at $55^{\circ} \mathrm{C}$ (annealing), and $1 \mathrm{~min}$ at $72{ }^{\circ} \mathrm{C}$ (elongation), with a final step at $72{ }^{\circ} \mathrm{C}$ for primer extension (5 $\mathrm{min})$. 
Table 1. Origins, vouchers, accession numbers in GenBank, and chromosome numbers (2n) of Argentinian species of Berberis and the outgroup

\begin{tabular}{|c|c|c|c|}
\hline Species & Origin & GenBank & $2 n$ \\
\hline B. bidentata Lechl. & Prov. Río Negro. Dpto. Bariloche: Pto. Blest, $\mathrm{B}_{59}$ & AF403383 & 28 \\
\hline B. bidentata Lechl. & Prov. Neuquén. Dpto Los Lagos: Nahuel Huapi lake, $\mathrm{B}_{109}$ & AF403368 & 28 \\
\hline B. darwinii Hook. & Prov. Río Negro. Dpto. Bariloche: Tallin Ahogado, $\mathrm{B}_{160}$ & AF403369 & 28 \\
\hline $\begin{array}{l}\text { B. trigona Kunze ex Poepp \& Endl. } \\
\text { (=B. linearifolia Phil.) }\end{array}$ & Prov. Río Negro. Dpto. Bariloche: Pto. Blest, $\mathrm{B}_{77}$ & $\mathrm{AF} 403382$ & 28 \\
\hline B. serrato-dentata Lechl. & Prov. Río Negro. Dpto. Bariloche: Cerro Chal-Huaco, $\mathrm{B}_{425}$ & AF403370 & 28 \\
\hline B. ilicifolia L. f. & Prov. Tierra del Fuego. Dpto. Ushuaia: Ushuaia, $\mathrm{B}_{545}$ & AF403371 & 28 \\
\hline B. comberi Sprague \& Sandwith & Prov. Neuquén. Dpto Loncopué: 40 National Road, $\mathrm{B}_{439}$ & AF403380 & 28 \\
\hline B. parodii Job & Prov. Neuquén. Dpto Los Lagos: Pichi Traful, $\mathrm{B}_{98}$ & AF403372 & 28 \\
\hline B. cabrerae Job & Prov. Río Negro. Dpto. Bariloche: Los Clavos lake, $\mathrm{B}_{373}$ & AF403381 & 28 \\
\hline B. heterophylla Juss. ex Poir. & Prov. Río Negro. Dpto. Pilcaniyeu: 23 National Road, $\mathrm{B}_{183}$ & AF403373 & 28 \\
\hline B. heterophylla Juss. & Prov. Río Negro. Dpto. Bariloche: $15 \mathrm{~km}$ to W Paso Flores, $\mathrm{B}_{494}$ & $\mathrm{AF} 403374$ & 56 \\
\hline B. buxifolia Lam. & Prov. Río Negro. Dpto. Bariloche: Cerro Otto, $\mathrm{B}_{42}$ & AF403375 & 56 \\
\hline B. buxifolia Lam. & Prov. Chubut. Dpto. Cushamen: 40 National Road, $\mathrm{B}_{140}$ & $\mathrm{AF} 403376$ & 56 \\
\hline B. microphylla G. Forst. & Prov. Tierra del Fuego: Dpto. Ushuaia: Ushuaia, $\mathrm{B}_{527}$ & AF403377 & 28 \\
\hline B. empetrifolia Lam. & Prov. Río Negro. Dpto. Bariloche: Steffen lake, $\mathrm{B}_{487}$ & AF403378 & 28 \\
\hline B. grevilleana Gillies ex Hook. \& Arn. & Prov. Mendoza. Dpto. Malargüe: Argentina, $\mathrm{B}_{355}$ & AF403379 & 28 \\
\hline B. trifoliolata Moric. & Texas, USA & AF174616 & - \\
\hline
\end{tabular}

B, M. C. J. Bottini.

PCR products were visualized on $1.5 \%$ agarose gel by electrophoresis and then purified using the QIAquick Gel Extraction Kit (Qiagen). Cycle sequencing products were analysed on an ABI Prism 7100 (Applied Biosystems) automated DNA sequencer.

The DNA sequences obtained were assembled and the boundaries of ITS1 and ITS2 were determined by comparison with the previously published sequences of B. trifoliolata (Jackson et al., 1999). Nucleotide sequences were aligned using the Clustal W 1.5 program (Thompson, Higgins \& Gibson, 1994). All sequences have been submitted to GenBank (AF403368-AF403383, Table 1). The aligned matrix is available from M.C.J.B. (michayhue@bigfoot.com).

Phylogenetic trees based on the data set were generated using the maximum parsimony (MP) package (Swofford, 1993) with PAUP 3.1.1 software following the heuristic search procedure [tree bisectionreconnection (TBR) option]. Different measures of homoplasy, such as the consistency index (CI), retention index (RI) (Kluge \& Farris, 1969; Farris, 1989), and g1 statistic (a measure of the skewness of the tree length distribution) (Hillis \& Huelsenbeck, 1992), were computed to estimate the amount of phylogenetic information in parsimony analysis. The g1 statistic was calculated by generating 1000 random parsimonious trees using the PAUP random trees option. Bootstrap analysis was carried out with 1000 replicates (Felsenstein, 1985) to estimate the reliability of the clades on the strict consensus tree. The decay index (Donoghue et al., 1992) was performed up to five steps
Table 2. Distinguishing features of the ITS1-5.8S-ITS2 region for 17 sequences (representing 13 species) of the Patagonian species of Berberis

\begin{tabular}{ll}
\hline Parameter & ITS1-5.8S-ITS2 \\
\hline Length range (bp) & $606-611$ \\
Length mean (bp) & 608.9 \\
Aligned length (bp) & 614 \\
G +C content range (complete matrix) & $310-318$ \\
G +C content mean (complete matrix) & 311 \\
Sequence divergence (\%) & $2.9-82.9$ \\
Number of indels (ingroup + outgroup) & 3 \\
Number of variable sites & 35 \\
Number of potentially informative sites & $32(5.3)$ \\
$\quad$ (\%) & $579(94.3)$ \\
Number of constant sites (\%) & $3(0.5)$ \\
Number of autapomorphic sites (\%) & \\
\hline
\end{tabular}

ITS, internal transcribed spacer.

longer than the shortest tree to determine the robustness of the clades found in the most parsimonious trees.

\section{RESULTS}

The distinguishing features of the aligned DNA sequences of the ITS1, 5.8S, and ITS2 regions of all 13 taxa used in this study are described in Table 2. Polymorphism for the sequences studied was not found. 
The length variation for the entire ITS region (including the $5.8 \mathrm{~S}$ cistron) ranged from 606 to $611 \mathrm{bp}$. The length of the combined ITS1 and ITS2 region in the Berberis taxa surveyed ranged from 447 to $454 \mathrm{bp}$, and the $\mathrm{G}+\mathrm{C}$ content varied from 23.62 to $27.16 \%$. The ITS1 region (227-231 bp) was slightly longer (9.07 bp) than the ITS2 region (220-224 bp). The 5.8S rDNA showed a uniform length of $159 \mathrm{bp}$ in all samples. The alignment presents a total of three indels: two in ITS1, composed of 1-3 bp at positions 118 and $72-74$, and one in ITS2, composed of 3 or 4 bp at positions 453-455/452-455.

After the alignment, the sequence data matrix contained 614 characters, 34 (5.5\%) of which were variable. Of these 34 variable characters, 26 (76.5\%) were substitutional mutations, one $(2.9 \%)$ was a 1-bp insertion/deletion (indel), and two (5.9\%) were multibp indels (one of $3 \mathrm{bp}$ and one of $4 \mathrm{bp}$ ).

The sequence divergence value obtained from the pairwise comparisons of Patagonian species was in the range $2.9-22.9 \%$ (Table 3 ). The highest divergence values were observed between B. trifoliolata (outgroup) and all ingroup species (77.1-82.9\%) (Table 3, column $18)$.

The analysis of parsimony using PAUP displayed five equal most parsimonious trees (length, 38; CI, 0.92 ; RI, 0.93; g1, $-0.47 ; P<0.01$ ). No noticeable differences were found in resolution between the trees. The CI value (0.92) indicates a low rate of homoplasy.
The strict consensus tree is shown in Figure 1. The bootstrap values were in the range $62-87 \%$, indicating that most of the branches were correctly supported. The decay index values showed that one or two evolutionary steps were needed to collapse the branches.

The strict consensus tree showed several nonresolved polytomies. Of these, one included three species, B. microphylla, B. grevilleana, and $B$. empetrifolia, whereas a terminal polytomy was formed by B. heterophylla, B. buxifolia, B. cabrerae, and B. parodii. Bootstrap and decay values are also indicated, and were significant in all cases (> 50\%).

\section{DISCUSSION}

Phylogenetic relationships between related species can be determined by comparing homologous sequences (Gielly \& Talberlet, 1994; Käss \& Wink, 1997). Coding sequences have been widely used to study phylogeny at higher taxonomic levels (family, tribe, etc.), but are less informative for the determination of relationships between closely related organisms (Gielly et al., 1996). At this level, noncoding regions seem to be more efficient (Buckler \& Holtsford, 1996).

In all the Patagonian species of Berberis analysed, ITS1 was longer than ITS2. This difference in size is in agreement with data already obtained from other flowering plants, i.e. the families Asteraceae (Baldwin,

Table 3. Pairwise divergence between taxa computed by comparing their unambiguously aligned DNA sequences. The absolute distance values are shown below the diagonal and the percentage mean distance values above the diagonal

\begin{tabular}{rrrrrrrrrrrrrrrrrrrr}
\hline & 1 & 2 & 3 & 4 & 5 & 6 & 7 & 8 & 9 & 10 & 11 & 12 & 13 & 14 & 15 & 16 & 17 \\
\hline 1 & - & 0 & 0 & 5.7 & 11.4 & 11.4 & 8.6 & 22.9 & 22.9 & 22.9 & 22.9 & 22.9 & 22.9 & 20.0 & 20.0 & 20.0 & 82.9 \\
2 & 0 & - & 0 & 5.7 & 11.4 & 11.4 & 8.6 & 22.9 & 22.9 & 22.9 & 22.9 & 22.9 & 22.9 & 20.0 & 20.0 & 20.0 & 82.9 \\
3 & 0 & 0 & - & 5.7 & 11.4 & 11.4 & 8.6 & 22.9 & 22.9 & 22.9 & 22.9 & 22.9 & 22.9 & 20.0 & 20.0 & 20.0 & 82.9 \\
4 & 2 & 2 & 2 & - & 11.4 & 11.4 & 8.6 & 22.9 & 22.9 & 22.9 & 22.9 & 22.9 & 22.9 & 20.0 & 20.0 & 20.0 & 82.9 \\
5 & 4 & 4 & 4 & 4 & - & 0 & 2.9 & 17.1 & 17.1 & 17.1 & 17.1 & 17.1 & 17.1 & 14.3 & 14.3 & 14.3 & 77.1 \\
6 & 4 & 4 & 4 & 4 & 0 & - & 2.9 & 17.1 & 17.1 & 17.1 & 17.1 & 17.1 & 17.1 & 14.3 & 14.3 & 14.3 & 77.1 \\
7 & 3 & 3 & 3 & 3 & 1 & 1 & - & 14.3 & 14.3 & 14.3 & 14.3 & 14.3 & 14.3 & 11.4 & 11.4 & 11.4 & 74.3 \\
8 & 8 & 8 & 8 & 8 & 6 & 6 & 5 & - & 0 & 0 & 0 & 0 & 0 & 8.6 & 8.6 & 8.6 & 82.9 \\
9 & 8 & 8 & 8 & 8 & 6 & 6 & 5 & 0 & - & 0 & 0 & 0 & 0 & 8.6 & 8.6 & 8.6 & 82.9 \\
10 & 8 & 8 & 8 & 8 & 6 & 6 & 5 & 0 & 0 & - & 0 & 0 & 0 & 8.6 & 8.6 & 8.6 & 82.9 \\
11 & 8 & 8 & 8 & 8 & 6 & 6 & 5 & 0 & 0 & 0 & - & 0 & 0 & 8.6 & 8.6 & 8.6 & 82.9 \\
12 & 8 & 8 & 8 & 8 & 6 & 6 & 5 & 0 & 0 & 0 & 0 & - & 0 & 8.6 & 8.6 & 8.6 & 82.9 \\
13 & 8 & 8 & 8 & 8 & 6 & 6 & 5 & 0 & 0 & 0 & 0 & 0 & - & 8.6 & 8.6 & 8.6 & 82.9 \\
14 & 7 & 7 & 7 & 7 & 5 & 5 & 4 & 3 & 3 & 3 & 3 & 3 & 3 & - & 0 & 5.7 & 80.0 \\
15 & 7 & 7 & 7 & 7 & 5 & 5 & 4 & 3 & 3 & 3 & 3 & 3 & 3 & 0 & - & 5.7 & 80.0 \\
16 & 7 & 7 & 7 & 7 & 5 & 5 & 4 & 3 & 3 & 3 & 3 & 3 & 3 & 2 & 2 & - & 80.0 \\
17 & 29 & 29 & 29 & 29 & 27 & 27 & 26 & 29 & 29 & 29 & 29 & 29 & 29 & 28 & 28 & 28 & - \\
\hline
\end{tabular}

1, B. bidentata 109; 2, B. bidentata 59; 3, B. darwinii 160; 4, B. trigona 77; 5, B. serrato-dentata 425; 6, B. ilicifolia 545; 7, B. comberi 439; 8, B. parodii 98; 9, B. cabrerae 373; 10, B. heterophylla 494; 11, B. buxifolia 42; 12, B. heterophylla 183; 13, B. buxifolia 140; 14, B. microphylla 527; 15, B. empetrifolia 487; 16, B. grevilleana $355 ; 17$, B. trifoliolata . 


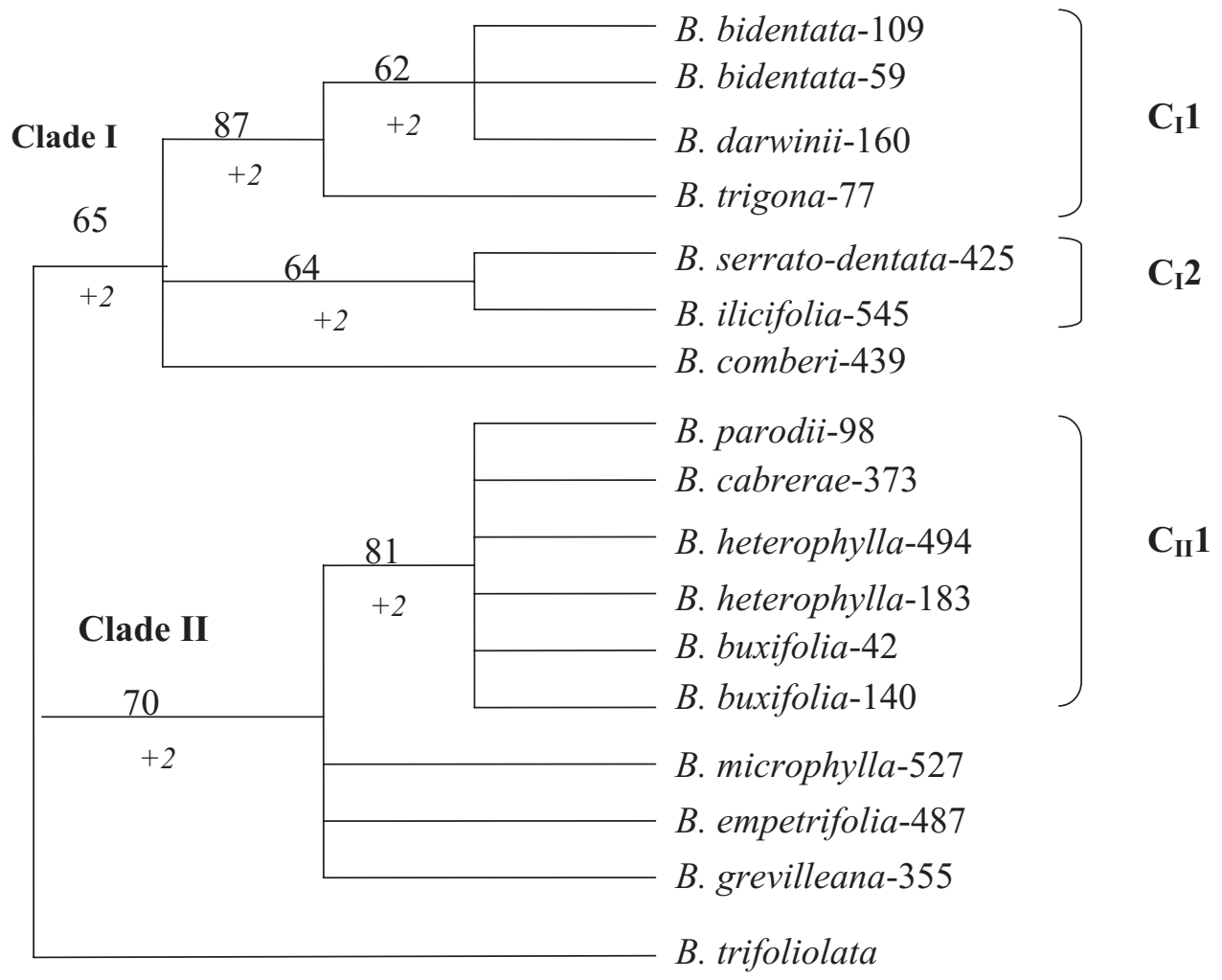

Figure 1. Strict consensus tree for Patagonian Berberis species and outgroup-based parsimony analysis on the combined internal transcribed spacer 1 (ITS1), ITS2, and 5.8S general sequence data. Bootstrap values from 1000 replicates are presented above the branches, and decay indices are given in italic below the branches.

1992; Cerbah et al., 1998), Fabaceae (Kollipara, Singh \& Hymowitz, 1997), and Fouquieriaceae (Schultheis \& Baldwin, 1999). However, in other families, for example Gentianaceae, ITS2 is longer than ITS1 (Yuan \& Küpfer, 1995).

ITS1 and ITS2 sequences are inherently rich in $\mathrm{G}+\mathrm{C}$, and portions of these regions are quite conserved amongst angiosperms (Soltis \& Soltis, 1998). The length and $\mathrm{G}+\mathrm{C}$ content of the ITS region in the genus Berberis were found to be typical of angiosperms (Baldwin et al., 1995). The highly conserved sequence GGCRY-(4-7N)-GYGYCAAGGAA in the ITS1 region across many plant families (Liu \& Schardl, 1994) was also found to be conserved in all species of Berberis (positions 150-170). Sequence variation in ITS1 and ITS2 of Berberis species was a result of point mutations rather than insertions/deletions (Table 2). The divergence values between Patagonian species were in the range $2.9-22.9 \%$, but higher divergence values, $77-82.9 \%$, were found between all Patagonian species and the outgroup B. trifoliolata (Table 3).

ITS data show that B. darwinii and B. bidentata constitute a clade, with $B$. trigona $(=B$. linearifolia $)$ as sister group $\left(\mathrm{C}_{\mathrm{I}} 1\right)$. B. bidentata could have originated from the hybridization of two diploid species, the putative parental species being $B$. darwinii and $B$. trigona (Orsi, 1974; Bottini et al., 1998, 1999a, 2000a, b; Bottini, 2000). B. bidentata grows together with its putative parents in some areas, notwithstanding that this species grows in particular ecological and geographical conditions, for example, disturbed soils. McDade (1992), investigating the effect of the inclusion of known hybrids in phylogenetic analyses, found that, for a hybrid taxon with recombinant traits, one of the likely placements is immediately basal to one of its parent species. In our ITS phylogeny (Fig. 1), $B$. trigona, one of the parental species, shows a basal placement, whereas B.darwinii, the hybrid, and $B$. bidentata, another parent, are more closely related. This result is in agreement with morphological studies, because, in the field, it is common to find individuals with characteristics intermediate between both putative parents, and also individuals morphologically most similar to B. darwinii, as revealed in this analysis (Fig. 1) (Bottini et al., 1998, 1999a).

The same ploidy level presented by these three species $(2 n=2 x=28)$ and the similarity demonstrated by studies of isozymes, seed proteins, and AFLP, together with the phylogenetic relationships shown in Figure 1, 
reinforce the hypothesis that $B$. darwinii, B. trigona, and $B$. bidentata constitute a homogamic hybrid complex (Bottini et al., 1999a, 2002; Bottini, 2000).

Another clade shown by the present molecular data is composed of B.ilicifolia and B. serratodentata $\left(\mathrm{C}_{\mathrm{I}} 2\right)$. The geographical distribution of these two species is allopatric in Argentina (Bottini, 2000), but sympatric in Regions X and XI of Chile (Landrum, 1999, 2003). According to Landrum, in this large area of overlap, the lines between these two species are sometimes unclear, and this can be explained by hybridization between the species. Beyond the region of overlap, the species are quite distinct as a result of leaf characters and the presence of spines in B. ilicifolia.

Berberis comberi, endemic to central western Argentina (Orsi, 1984), is found in only a few localities in the Patagonian deserts of Mendoza and Neuquén provinces that have dramatic seasonal changes (Landrum, 1999). The morphology of B. comberi is not clearly related to any other species of Berberis in southern South America, except perhaps B. grevilleana. Both species share the characteristic of having seeds that fuse together in a mass in the mature fruit (Landrum, 1999). However, such a relationship based on morphology is not revealed in the molecular analysis of ITS sequences (Fig. 1).

Clade $\mathrm{C}_{\mathrm{II}} 1$ is characterized by both diploid and polyploid species: B. buxifolia, B. heterophylla $(4 x)$ and B. cabrerae and B. parodii $(2 x)$. B. heterophylla is widely distributed in the Patagonian steppe (xeric environments), whereas $B$. buxifolia has a more extensive distribution range, growing in Austrocedrus forest, a mixed forest of Austrocedrus Florin \& Boutelje and Nothofagus Blume, and in the forest-steppe ecotone (Bottini et al., 2000a). B. parodii grows in the forest of evergreen $N$. dombeyi (Mirb.) Oerst. and deciduous $N$. antarctica (G. Forst) Oerst. and overlaps in its habitat with B. buxifolia. On the basis of morphological, isozymatic, chromosome, and AFLP studies, these three species constitute a polyploid hybrid complex (Bottini, 2000; Bottini et al., 2002).

Beberis parodii $(2 n=28)$, or a very similar species, could be involved in the origin of B. buxifolia $(2 n=56)$ and $B$. heterophylla $(2 n=56)$. Isozymatic data have shown that B.buxifolia, B. heterophylla, and $B$. parodii have similar interspecific genetic indices and a similar degree of isozymatic variability, suggesting a recent divergence between them (Bottini, 2000). The polyploid species do not show a significant increase in the amount of AFLP bands compared with the diploid species, suggesting autopolyploidy, as do the isozyme data (Bottini, 2000; Bottini et al., 2002). B. buxifolia and B. heterophylla are tetraploid, and therefore would be expected to be derived species within the group. The analysis of the ITS sequences revealed various patterns in hybrid species. In some cases, both parental sequences were retained (Sang, Crawford \& Stuessy, 1995). More commonly, however, concerted evolution resulted in numerous identical or near-identical sequences within a genome. Concerted evolution of the rDNA system and, consequently, of the ITS region has been well documented in plants (Hillis \& Dixon, 1991). This process homogenizes different members of multiloci systems faster than would be expected with other evolutionary mechanisms (Wendel, Schnabel \& Seelanen, 1995). The process is continuous during speciation, and should be deficient or unfinished in very recent species (Odorico \& Miller, 1997). It is interesting to point out that these three species are in the same clade. However, the ITS results are not sufficiently informative to elucidate the origin of this complex.

Although B. cabrerae (=B. montana according to Landrum, 1999) has an identical ITS sequence to that of $B$. buxifolia, B. heterophylla, and B. parodii, there is no obvious explanation for its placement in this clade. This species is most likely to be confused with B. microphylla (Landrum, 1999). Our ITS studies suggest that many of the Patagonian species of Berberis are in the process of speciation, and so this group offers abundant opportunities to study the early stages of evolutionary divergence.

Berberis microphylla, B. empetrifolia, and B. grevilleana constitute a polytomy. It would not be surprising that they also form a hybrid complex, because $B$. grevilleana hybridizes with B. empetrifolia, and $B$. montana, which can be confused with $B$. microphylla, probably hybridizes with B. empetrifolia (Landrum, 1999).

The combination of available cytogenetic and biochemical data with AFLP data and the results obtained in the present work demonstrates that the taxonomic treatment of Berberis must be reevaluated. An example of this is B. microphylla sensu Landrum (1999). This author placed B. microphylla G. Forst, B. buxifolia, B. heterophylla, and B. parodii (amongst others) under the name B. microphylla. This species does not appear to be monophyletic based on current sampling. On the basis of the data obtained, we suggest that $B$. microphylla $(2 n=28)$ should be distinguished from $B$. parodii $(2 n=28)$ and the tetraploids $(2 n=56) B$. buxifolia and B. heterophylla. Moreover, we consider that the latter species should also be considered as distinct. This, of course, does not mean that B. buxifolia, B. parodii, and B. heterophylla represent strictly independent lineages, but there exist characters, such as AFLP and isozymes, that permit them to be differentiated. Answers with regard to the origin and relationships of these species await more intensive studies, but, for the present, it is best to recognize them as distinct species. 


\section{ACKNOWLEDGEMENTS}

The authors would like to thank Dr Yolanda Loarce for her help with data analysis and Viviana Confalonieri for her valuable suggestions. This research was supported by grants from CICYT (Comisión Asesora de Ciencia y Tecnología, Grant No. AGF97-810) of Spain, Agencia Nacional de Promoción Científica y Tecnológica, CONICET (Consejo Nacional de Investigaciones Científicas y Técnicas) of Argentina, and Universidad Austral de Chile (DID S-2005-76) of Chile. Alfredo De Bustos is supported by the Ramón y Cajal Programme of MCYT (Ministerio de Ciencia y Tecnologia), Spain.

\section{REFERENCES}

Ahrend LWA. 1961. Berberis and Mahonia. A taxonomical revision. Botanical Journal of the Linnean Society 57: 1-410.

Baldwin BG. 1992. Phylogenetic unity of the internal transcribed spacers of nuclear ribosomal DNA in plants: an example for the Compositae. Molecular Phylogenetics and Evolution 1 (1): 3-16.

Baldwin BG, Sanderson MJ, Porter JM, Wojciechowski MF, Campbell CS, Donoghue MJ. 1995. The ITS region of nuclear ribosomal DNA: a valuable source of evidence on Angiosperm phylogeny. Annals of the Missouri Botanical Garden 82: 247-277.

Bottini MCJ. 2000. Estudios multidisciplinarios en las especies patagónicas argentinas del género Berberis (Berberidaceae). PhD Thesis, Universidad de Buenos Aires.

Bottini MCJ, Bustos C, Bran D. 1993. Arbustos de la Patagonia: Calafate y Michay. Presencia - INTA 30: 5-9.

Bottini MCJ, De Bustos Rodríguez A, Jouvé de la Barreda N, Poggio L. 2002. AFLP characterization of natural Patagonian population of Berberis (Berberidaceae). Plant Systematics 231: 133-142.

Bottini MCJ, Greizerstein EJ, Aulicino MB, Poggio L. 2000a. Relationships among genome size, environmental conditions and geographical distribution in natural populations of NW Patagonian species of Berberis L. (Berberidaceae). Annals of Botany 86: 565-573.

Bottini MCJ, Greizerstein EJ, Poggio L. 1999a. Ploidy levels and their relationships with the rainfall in several populations of Patagonian species of Berberis L. Caryologia 44: 93-107.

Bottini MCJ, Greizerstein EJ, Poggio L. 2000b. Estudios electroforéticos de proteínas seminales (SDS-PAGE) en las especies patagónicas del género Berberis (Berberidaceae). Boletin de la Sociedad Argentina de Botanica 35 (3-4): 245258.

Bottini MCJ, Orsi MC, Greizerstein EJ, Poggio L. 1998. Relaciones fenéticas entre las especies del género Berberis del NO de la Región Patagónica. Darwiniana 35: 115-127.

Bottini MCJ, Premoli AC, Poggio L. 1999b. Hybrid speciation in Berberis L.: an isoenzymatic approach. In: XVI International Botanical Congress, St. Louis, MO, USA. St Louis: XVI International Botanical Congress Press, 363.
Brickell CH. 1989. The Royal Horticultural Society gardeners encyclopedia of plants and flowers. London: Dorling Kindersley Publishers.

Buckler IES, Holtsford TP. 1996. Zea systematics: ribosomal ITS evidence. Molecular Biology and Evolution 13: 612622.

Cerbah M, Souza-Chies T, Jubier MF, Lejeune B, SiljakYakovlev V. 1998. Molecular phylogeny of the genus Hypochaeris using internal transcribed spacers of nuclear rDNA: inference for chromosomal evolution. Molecular Biology and Evolution 15 (3): 345-354.

De Bustos A, Jouve N. 2002. Phylogenetic relationships of the genus Secala based on the characterization of rDNA ITS sequences. Plant Systematics and Evolution 235: 147-154.

De Bustos A, Loarce Y, Jouve N. 2002. Species relationships between antifungal chitinase and nuclear rDNA (internal transcribed spacer) sequences in the genus Hordeum. Genome 45: 339-347.

Donoghue MJ, Olmstead RG, Smith JF, Palmer JD. 1992. Phylogenetic relationships of Dipsacales based on rbcl sequences. Annals of the Missouri Botanical Garden 79: 333345 .

Dubouzet JG, Shinoda K. 1999. ITS DNA sequence relationships between Lilium concolor Salisb., L. dauricum KerGawl. and their putative hybrid, L. maculatum Thunb. Theoretical and Applied Genetics 98: 213-218.

Eckenrode VK, Arnold J, Meagher RB. 1984. Comparison of the nucleotide sequence of soybean 18s rRNA with the sequences of other small-subunit rRNAs. Journal of Molecular Evolution 21: 259-269.

Fajardo Morales V. 1992. Alcaloides en especies del género Berberis de Chile. In: Muñoz OM, ed. Química de la flora de Chile. Santiago: Universidad de Chile, 215-240.

Farris JS. 1989. The retention index and rescaled consistency index. Cladistics 5: 417-419.

Felsenstein J. 1985. Confidence limits on phylogenetics: an approach using the bootstrap. Evolution 39: 783-791.

Gielly L, Talberlet P. 1994. The use of chloroplast DNA to resolve plant phylogenies: noncoding versus $r b c \mathrm{~L}$ sequences. Molecular Biology and Evolution 11: 769-777.

Gielly L, Yuan YM, Kupfer P, Taberlet P. 1996. Phylogenetic use of noncoding regions in the genus Gentiana L. Chloroplast trnL (UAA) intron versus nuclear ribosomal internal transcribed spacer sequences. Molecular Biology and Evolution 5: 460-466.

Hillis DM, Dixon MT. 1991. Ribosomal DNA: molecular evolution and phylogenetic inference. Quarterly Review of Biology 6 (4): 411-439.

Hillis DM, Huelsenbeck JP. 1992. Signal noise, and reliability in molecular phylogenetic analyses. Journal of Heredity 83: $189-195$.

Hsiao C, Chatterton NJ, Asay K, Jensen KB. 1994. Phylogenetic relationships of 10 grass species: an assessment of phylogenetic utility of the internal transcribed spacer region in nuclear ribosomal DNA in monocots. Genome 37: 112-120.

Hsiao C, Chatterton NJ, Asay K, Jensen KB. 1995. Phylogenetic relationships of the monogenomic species of the wheat tribe, Triticeae (Poaceae), inferred from nuclear rDNA 
(internal transcribed spacer) sequences. Genome 38: 211223.

Jackson RB, Moore LA, Hoffmann WA, Pockman WT, Linder CR. 1999. Ecosystem rooting depth determined with caves and DNA. Proceedings of the National Academy of Science 93: 11 387-11 392.

Käss E, Wink M. 1997. Phylogenetic relationships in the Papilionoideae (family Leguminosae) based on nucleotide sequences of cpDNA ( $r b c \mathrm{~L}$ ) and ncDNA (ITS 1 and 2). Molecular Phylogenetics and Evolution 8: 65-88.

Kim Y-D, Kim S-H, Landrum LR. 2004. Taxonomic and phytogeographic implications from ITS phylogeny in Berberis (Berberidaceae). Journal of Plant Research 117: 175-182.

Kluge AG, Farris JS. 1969. Quantitative phyletics and the evolution of anurans. Systematic Zoology 18: 1-32.

Kollipara P, Singh RJ, Hymowitz T. 1997. Phylogenetic and genomic relationships in the genus Glycine Willd. based on sequences from the ITS region of nuclear rDNA. Genome 40: $57-80$.

Laferrière JE. 1991. Transformer of Mahonia trifoliolata var glauca of Berberis. Madroño 38 (1): 59-60.

Landrum LR. 1999. Revision of Berberis (Berberidaceae) in Chile and adjacent Southern Argentina. Annals of the Missouri Botanical Garden 86: 793-834.

Landrum LR. 2003. Berberidaceae. In: Marticorena C, Rodrìguez R, eds. Flora de Chile, 2 (2). Concepción: University de Concepción, 1-23.

Lashermes P, Combes MC, Trouslot P, Charrier A. 1997. Phylogenetic relationships of coffee-tree species (Coffea L.) as inferred from ITS sequences of nuclear ribosomal DNA. Theoretical and Applied Genetics 94: 947-955.

Liu J, Schardl CL. 1994. A conserved sequence in internal transcribed spacer 1 of plant nuclear rDNA genes. Plant Molecular Biology 26: 775-778.

Loconte H. 1993. Berberidaceae. In: Kubitzki K, Rohwer JG, Brittrich V, eds. The family and genera of vascular plants, Vol. 2. Spring-Verlag, 147-152.

Martínez Crovetto R. 1980. Apuntes sobre la vegetación de los alrededores del Lago Cholila. Corrientes: University Nacional del Noroeste.

McDade LA. 1992. Hybrids and phylogenetic systematics. II. The impact on cladistic analysis. Evolution 46: 1329-1346.

Odorico DM, Miller DJ. 1997. Variation in the ribosomal internal transcribed spacers and 5.8 rDNA among five species of Acropora (Cnidaria; Scleractinia): patterns of variation consistent with reticulate evolution. Molecular Biology and Evolution 14: 465-473.

Orsi MC. 1974. El género Berberis en la República Argentina. PhD Thesis, Facultad de Ciencias Naturales y Museo, Universidad Nacional de La Plata, La Plata.

Orsi MC. 1976. Sinopsis de las especies argentinas del género Berberis (Berberidaceae). Boletin de la Sociedad Argentina de Botanica 17: 127-149.
Orsi MC. 1984. Berberidaceae. In: Correa MN, ed. Flora Patagónica, Secc. 4a Buenos Aires: INTA, 325-348.

Sang T, Crawford DJ, Stuessy TF. 1995. Documentation of reticulate evolution in peonies (Paeonia) using internal transcribed spacer sequences of nuclear ribosomal DNA: implications for biogeography and concerted evolution. Proceedings of the National Academy of Science 92: 68136817.

Schultheis LM, Baldwin BG. 1999. Molecular phylogenetics of Fouquieriaceae: evidence from nuclear rDNA ITS studies. American Journal of Botany 86 (4): 578-589.

Smith DE, Klein AS. 1994. Phylogenetic inferences on the relationship of North American and European Picea species based on nuclear ribosomal $18 \mathrm{~S}$ sequences and the internal transcribed spacer 1 region. Molecular Phylogenetics and Evolution 3 (1): 17-26.

Soltis DE, Soltis PS. 1998. Choosing an approach and an appropriate gene for phylogenetic analysis. In: Soltis DE, Soltis PS, Doyle JJ, eds. Molecular systematics of plants II: DNA sequencing. Boston, MA: Kluwer Academic Publishers, $1-42$.

Sun Y, Skinner DZ, Liang GH, Hulbert SH. 1994. Phylogenetic analysis of Sorghum and related taxa using internal transcribed spacers of nuclear ribosomal DNA. Theoretical and Applied Genetics 89: 26-32.

Swofford D. 1993. PAUP: phylogenetic analysis using parsimony, Version 3.1. Champaign, IL: Illinois Natural History Survey.

Thompson JD, Higgins DG, Gibson TJ. 1994. CLUSTAL W: improving the sensitivity of progressive multiple sequence alignment through sequence weighting, position-specific gap penalties and weight matrix choice. Nucleic Acids Research 22 (22): 4673-4680.

Wendel JF, Schnabel A, Seelanen T. 1995. Bidirectional interlocus concerted evolution following allopolyploid speciation in cotton (Gossypium). Proceedings of the National Academy of Science 92: 280-284.

White TJ, Bruns T, Lee S, Taylor J. 1990. Amplification and direct sequencing of fungal ribosomal RNA genes for phylogenetics. In: Innis M, Gelfand D, Sninsky J, White T, eds. PCR protocols: a guide to methods and applications. San Diego: Academic Press, 315-322.

Yuan YM, Küpfer P. 1995. Molecular phylogenetics of the subtribe Gentianinae (Gentianaceae) inferred from the sequences of the internal transcribed spacers (ITS) of nuclear ribosomal DNA. Plant Systematics and Evolution 196: $207-226$.

Zomlefer WB, Whitten WM, Williams NH, Judd WS. 2003. An overview of Veratrum s.l. (Liliales: Melanthiaceae) and an infrageneric phylogeny based on ITS sequence data. Systematic Botany 28 (2): 250-269. 